J. Dairy Sci. 97:1529-1534

http://dx.doi.org/10.3168/jds.2013-7132

(C) American Dairy Science Association ${ }^{\circledR}, 2014$.

\title{
Short communication: Effectiveness of tools provided by a dairy company on udder health in Dutch dairy farms
}

\author{
W. Steeneveld, ${ }^{* 1}$ A. G. J. Velthuis, $\nmid$ and H. Hogeveen ${ }^{\star} \neq$ \\ ${ }^{*}$ Chair Group Business Economics, Wageningen University, 6706 KN Wageningen, the Netherlands \\ †GD Animal Health Service, 7418 EZ Deventer, the Netherlands \\ fDepartment of Farm Animal Health, Faculty of Veterinary Medicine, Utrecht University, 3584 CL Utrecht, the Netherlands
}

\section{ABSTRACT}

A Dutch dairy company initiated a quality system to support dairy farmers to improve sustainability on their farm. Improvement of udder health is defined by the dairy company as one of the sustainability items. A part of that quality system is to offer farmers 3 tools to improve the udder health status of the herd. The first tool is an Udder Health Workshop at which farmers make a farm-specific action plan to improve the udder health situation in their herd. The second tool is the Udder Health Navigator, which is an internet-based program to gain insight in the actual udder health situation at the farm. The third tool is the Udder Health Checklist, which is available on the internet and it identifies farmspecific risks for udder health problems. The aim of this study was to evaluate the effectiveness of these tools in improving udder health. The bulk milk somatic cell count (BMSCC) was used as the measure of herd udder health performance. In total, 605 farms attended the Udder Health Workshop, 988 farms completed the Udder Health Navigator, and 1,855 farms completed the Udder Health Checklist in 2012. Information on BMSCC records (2 records per month) was available for 12,782 Dutch dairy farms during the years 2011 and 2012. For every farm, the average BMSCC of all months during the years 2012 and 2011 were calculated. This resulted in 306,768 average monthly observations of the BMSCC. Subsequently, all months after the completion of one of the tools were assigned a 1 , and all other months were assigned a 0 . A statistical analysis was carried out to compare the average monthly BMSCC of the farms that completed one or more tools with farms that did not complete one of the tools. Both completing the Udder Health Navigator and the Udder Health Checklist had a significant association with a lower average monthly BMSCC. The effect of the Udder Health Navigator and Udder Health Checklist on the BMSCC

Received June 13, 2013.

Accepted November 13, 2013

${ }^{1}$ Corresponding author: wilma.steeneveld@wur.nl were greater in herds with a BMSCC in 2011 of 200,000 to 250,000 cells $/ \mathrm{mL}$ and even greater for herds with a BMSCC above 250,000 cells $/ \mathrm{mL}$ compared with herds with a BMSCC in 2011 of 150,000 to 200,000 cells $/ \mathrm{mL}$ or less than 150,000 cells $/ \mathrm{mL}$. It is difficult to draw conclusions on the effect of the Udder Health Workshop due to overlap in participation between the tools. The results suggest that completing the web tools is associated with a reduction in the BMSCC of the herd.

Key words: udder health, bulk milk somatic cell count, dairy

\section{Short Communication}

Dairy companies demand high-quality bulk milk from dairy farms because losses can be high if the quality of dairy products is insufficient (e.g., Barbano et al., 2006; Velthuis et al., 2009). Therefore, a lot of attention is focused on the technical quality of milk, such as the bulk milk SCC (BMSCC; e.g., Berry et al., 2006), total bacterial count (e.g., Elmoslemany et al., 2009), and antimicrobial drug residues (e.g., Sischo et al., 1997). Recently, dairy companies have, however, paid more attention to sustainability items, such as decreasing $\mathrm{CO}_{2}$ emissions and improving animal welfare. In the Netherlands, dairy companies look beyond just the technical quality of milk and also pay attention to animal health and welfare and $\mathrm{CO}_{2}$ emissions of the dairy farms delivering milk. The dairy industry is interested in reducing the incidence of mastitis on dairy farms because it is associated with animal welfare (Lam et al., 2013).

As an indication of improved udder health on the dairy farm, the BMSCC can be used, as it is internationally used as a measure of herd udder health performance. Farms with more subclinical mastitis have higher BMSCC and, consequently, higher economic losses. For instance, Hogeveen et al. (2011) reported that total economic losses (due to clinical and subclinical mastitis) varied for farms with 65 cows from $€ 17 /$ cow per year on a farm with a BMSCC of $<100,000$ cells/mL to $€ 198 /$ cow per year on a farm with a BM- 
SCC $>400,000$ cells $/ \mathrm{mL}$. Management practices have been described that are effective in reducing BMSCC and that can help to improve the udder health situation of a farm (e.g., Barkema et al., 1998; Huijps et al., 2010; Dufour et al., 2011). For instance, postmilking teat disinfection and milking subclinical cows last have high efficacies in reducing BMSCC (Huijps et al., 2010). But also the use of external resources, such as regular visits by a veterinarian, was associated with a lower BMSCC (Cicconi-Hogan et al., 2013).

To start applying the advised management practices or to use external resources means a change in behavior of the farmer. Among others, attitudes and knowledge are important determinants of farmer behavior (e.g., Ellis-Iversen et al., 2010; Jansen et al., 2010a,b). It has been reported that a change in certain management practices was associated with a decrease in BMSCC (Jansen et al., 2010b). In addition, instruction cards, checklists, and other tools are effective in improving udder health when motivated farmers are involved (Jansen et al., 2010a).

Recently, a Dutch dairy company initiated a quality system to support dairy farmers to improve sustainability on their farm. Improvement of animal health and welfare is one of the sustainability items in this quality system. A part of that quality system is to offer farmers 3 tools to improve the udder health status of the herd. The first tool is the Udder Health (UH) Navigator, which is only available for the dairy farmers at the website of the dairy company. With the UH Navigator, a farmer can gain insight into the actual udder health status of the herd, which is then compared with the status of the previous year and to the desired status by the dairy company. In the UH Navigator, a farmer needs to enter information on udder health of the farm over the last year (e.g., percentage of cows with high SCC, the number of treated clinical mastitis cases in the last year, the geometric average BMSCC of the last year, and, if available, the results of bulk tank milk culturing of the last year). Subsequently, the entered information is transformed to a visual representation. For every entered value, a judgment is provided with corresponding colors (good $=$ dark green, satisfactory $=$ light green, moderate $=$ orange, and poor $=$ red). If the farmer entered information on bacteriological culturing, then information is also provided on whether the cause of udder health problems is related to environmental or contagious pathogens. In addition, advice on how to lower the infection pressure by environmental and contagious pathogens is then provided. The second tool is the UH Workshop. During a half day, a veterinarian and an advisor of the dairy company provide practical advice on how to improve the udder health of the herd. In preparation for the UH Workshop, the participants are asked to fill in the UH Navigator. Results of the UH Navigator are discussed, and results are compared with the results of the other participants. The UH Workshop is attended by approximately 10 farmers and is organized on one of the attending farms. At the end of the UH Workshop, all participants return to their farms with a farm-specific action plan to improve udder health. On the form of the action plan, a farmer describes the goal to reach (e.g., lowering average yearly BMSCC to 150,000 cells $/ \mathrm{mL}$ ), the measures the farmer will take to reach this goal (e.g., milking cows with high SCC last or wearing milking gloves), and when the measures will be implemented (e.g., next month). The third tool is the UH Checklist, which is also available for the dairy farmers at the website of the dairy company. The UH Checklist must be completed by the farmer together with the herd veterinarian. It aims to investigate the risks for udder health problems at the farm and provides measures for prevention and treatment. The UH Checklist contains of a list of 32 questions regarding the milking process (e.g., Do you use milking gloves?), treatment of mastitis (e.g., Is bacteriological culturing performed for cows with clinical mastitis?), resistance (e.g., Are minerals provided in the dry period?), and infection pressure (e.g., Are cows with clinical mastitis milked last?). A separate UH Checklist exists for farmers with an automatic milking system. The results of the UH Checklist should be discussed with the veterinarian. The UH workshop and UH Navigator are developed by the dairy company in collaboration with the Dutch Udder Health Centre (UGCN, Deventer, the Netherlands). The UH Checklist is developed by the UGCN, and is also available at their website (UGCN, 2013). Because the use of these tools is associated with attitude and behavior of the farmer, it can be hypothesized that using these 3 tools can improve the udder health status of the herd.

The aim of this study was to evaluate the effectiveness of the UH Workshop, UH Navigator, and UH Checklist (in the supplemental file; http://dx.doi.org/10.3168/ jds.2013-7132) in improving the udder health situation of the herd. The BMSCC level of the herd in the months following the UH interventions was used as a measure for the udder health situation of the herd.

Data on which farmers participated in 2012 in the UH Workshop, UH Navigator, and UH Checklist, including the date of participation, were provided by the dairy company. In total, 605 farms attended the $\mathrm{UH}$ Workshop, 988 farms used the UH Navigator, and 1,855 farms completed the UH Checklist. In total, 494 farms completed 2 tools (i.e., 352 farmers completed both the UH Workshop and the UH Navigator, 33 farmers completed both the UH Workshop and the UH Checklist, and 109 farmers completed both the UH Navigator and 
Table 1. Descriptive statistics about the monthly average bulk milk SCC (cells $/ \mathrm{mL} \times 1,000$ ) of the herds according to whether the farmers completed the tools Udder Health (UH) Navigator, UH Checklist, and UH Workshop for at least 1 mo or not

\begin{tabular}{|c|c|c|c|c|}
\hline \multirow[b]{2}{*}{ Item } & \multicolumn{4}{|c|}{ Bulk milk SCC } \\
\hline & Average & Median & $\begin{array}{l}5 \text { th }-95 \text { th } \\
\text { percentile }\end{array}$ & SD \\
\hline Did not complete UH Navigator $(\mathrm{n}=302,307)$ & 202 & 191 & $94-350$ & 80 \\
\hline Completed UH Checklist $(\mathrm{n}=6,702)$ & 188 & 177 & $91-322$ & 71 \\
\hline Did not complete UH Checklist $(\mathrm{n}=300,066)$ & 202 & 191 & $94-350$ & 80 \\
\hline Completed UH Navigator and UH Checklist $(\mathrm{n}=580)$ & 168 & 162 & $87-281$ & 59 \\
\hline Completed UH Navigator and UH Workshop $(\mathrm{n}=607)$ & 177 & 169 & $87-296$ & 66 \\
\hline Completed UH Checklist and UH Workshop $(\mathrm{n}=116)$ & 169 & 162 & $85-263$ & 59 \\
\hline Completed UH Navigator, UH Checklist and UH Workshop $(\mathrm{n}=77)$ & 164 & 157 & $87-281$ & 57 \\
\hline
\end{tabular}

the UH Checklist) and 116 farms completed all 3 tools. The dairy company also provided for all farms data on BMSCC (2 records per month) for the years 2011 and 2012. In total, 644,248 BMSCC records of 13,922 dairy farms were provided. Only farms were selected that had 48 BMSCC records (24 per year), which resulted in a final data set of 12,782 dairy farms with 613,536 BMSCC records. For every farm, the average BMSCC of each month during the years 2012 and 2011 were calculated. This resulted in 306,768 average monthly observations of the BMSCC. Subsequently, all months after the completion of the UH Navigator were assigned with a $1(\mathrm{n}=4,461 \mathrm{mo})$ and all other months were assigned with a 0 . The same was performed for the UH Checklist (6,702 mo assigned with a 1) and the UH Workshop (1,003 mo assigned with a 1).

A statistical analysis was carried out to compare the average monthly BMSCC of the farms that completed 1 or more tools with farms that did not complete 1 of the tools. The model included year (2011 or 2012), month within year (12 categories), completion of the

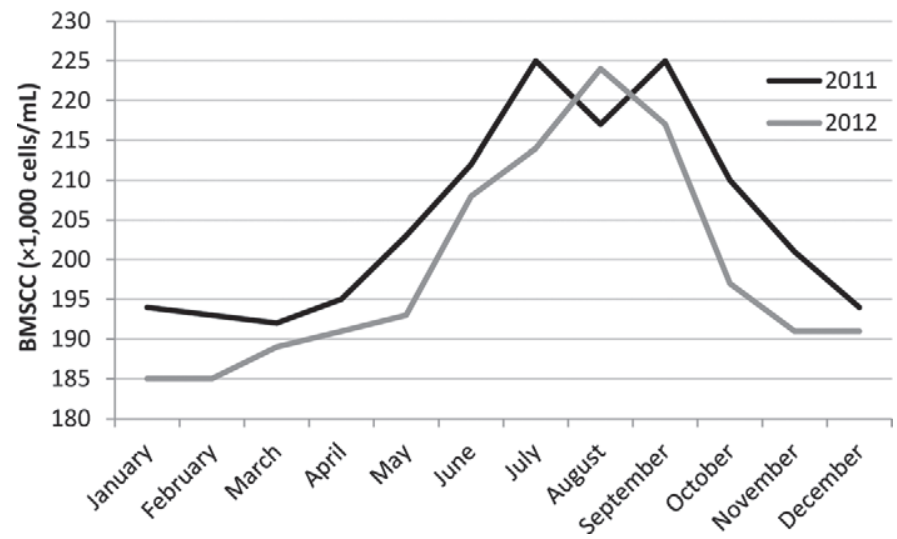

Figure 1. Average monthly bulk milk SCC (BMSCC) throughout the years 2011 and 2012 for the 12,782 farms in the study.
UH Navigator for at least 1 mo (1 or 0 ), completion of the UH Checklist for at least 1 mo ( 1 or 0$)$, completion of the UH Workshop for at least 1 mo ( 1 or 0$)$, and the interaction terms between the 3 tools. Also, the average monthly BMSCC of the farm in 2011 (categorized as <150,000, 150,000-200,000, 200,000-250,000 cells/ $\mathrm{mL}$, or $>250,000$ cells $/ \mathrm{mL}$ ) was included, as well as the interaction of this variable with each of the 3 tools. An autoregressive covariance structure accounting for repeated months (coded 1 to 12 ) within a year of a herd was incorporated. All variables were analyzed using a backward stepwise procedure. Only variables at $P \leq$ 0.05 in the Wald test were retained in the model. The initial model was

$$
\begin{gathered}
\text { BMSCC }_{i j k}=\beta_{0}+\beta_{1}+\beta_{2} \times \text { month (year) } \\
+\beta_{3} \times \text { BMSCC2011 }+\beta_{4} \times \text { UH Navigator } \\
+\beta_{5} \times \text { UH Checklist }+\beta_{6} \times \text { UH Workshop }+\beta_{7} \\
\times \text { UH Navigator } \times \text { UH Checklist }+\beta_{8} \times \mathrm{UH} \\
\text { Navigator } \times \text { UH Workshop }+\beta_{9} \times \text { UH Checklist } \\
\times \text { UH Workshop }+\beta_{10} \times \mathrm{UH} \text { Navigator } \times \mathrm{UH} \\
\text { Checklist } \times \text { UH Workshop }+\beta_{11} \times \text { BMSCC2011 } \\
\times \text { UH Navigator }+\beta_{12} \times \text { BMSCC2011 } \\
\times \text { UH Checklist }+\beta_{13} \times \text { BMSCC2011 } \\
\quad \times \text { UH Workshop }+\rho \varepsilon_{i j k},
\end{gathered}
$$

where $\mathrm{BMSCC}_{i j k}$ is the average monthly BMSCC of farm $i$ in tool category $j$ in month $k$. The model included year, month within year, average BMSCC of 2011 (BMSCC2011), and UH Workshop, UH Navigator, and UH Checklist (the variables whether the tools had been completed for at least 1 mo or not). Also, variables were included to test for combined effects of 2 tools (UH Workshop $\times$ UH Navigator, UH Workshop 
Table 2. Coefficient estimates $(\beta)$, SE, and $P$-values of the final mixed model for monthly average bulk milk SCC (BMSCC)

\begin{tabular}{|c|c|c|c|}
\hline Variable $^{1}$ & $\beta$ & $\mathrm{SE}$ & $P$-value \\
\hline Intercept & 270.52 & 0.618 & \\
\hline Year & & 0.742 & $<0.0001$ \\
\hline 2011 & 2.54 & - & \\
\hline 2012 & Ref. $^{2}$ & & \\
\hline BMSCC in 2011 & & & $<0.0001$ \\
\hline$<150,000$ cells $/ \mathrm{mL}$ & -152.83 & 0.533 & \\
\hline $150,000-200,000$ cells $/ \mathrm{mL}$ & -104.05 & 0.484 & \\
\hline $200,000-250,000$ cells $/ \mathrm{mL}$ & -62.71 & 0.497 & \\
\hline$>250,000$ cells $/ \mathrm{mL}$ & Ref. & - & \\
\hline UH Navigator & & & $<0.0001$ \\
\hline Completed & -29.80 & 3.363 & \\
\hline Not completed & Ref. & - & \\
\hline UH Checklist & & & 0.0003 \\
\hline Completed & -14.43 & 2.518 & \\
\hline Not completed & Ref. & - & \\
\hline Month within year & & & $<0.0001$ \\
\hline January 2011 & 0.32 & 0.732 & \\
\hline February 2011 & -1.04 & 0.731 & \\
\hline March 2011 & -2.42 & 0.731 & \\
\hline April 2011 & 1.34 & 0.730 & \\
\hline May 2011 & 8.71 & 0.728 & \\
\hline June 2011 & 17.81 & 0.725 & \\
\hline July 2011 & 31.03 & 0.718 & \\
\hline August 2011 & 22.70 & 0.705 & \\
\hline September 2011 & 30.96 & 0.679 & \\
\hline October 2011 & 16.54 & 0.625 & \\
\hline November 2011 & 7.35 & 0.507 & \\
\hline December 2011 & Ref. & - & \\
\hline January 2012 & -6.93 & 0.742 & \\
\hline February 2012 & -6.82 & 0.741 & \\
\hline March 2012 & -2.13 & 0.739 & \\
\hline April 2012 & -0.32 & 0.734 & \\
\hline May 2012 & 1.34 & 0.731 & \\
\hline June 2012 & 16.94 & 0.728 & \\
\hline July 2012 & 22.25 & 0.720 & \\
\hline August 2012 & 32.76 & 0.707 & \\
\hline September 2012 & 26.46 & 0.681 & \\
\hline October 2012 & 5.71 & 0.627 & \\
\hline November 2012 & 0.05 & 0.509 & \\
\hline December 2012 & Ref. & - & \\
\hline BMSCC $2011 \times$ UH Navigator completed & & & $<0.0001$ \\
\hline$<150,000$ cells $/ \mathrm{mL} \times \mathrm{UH}$ Navigator completed & 32.32 & 4.012 & \\
\hline $150,000-200,000$ cells $/ \mathrm{mL} \times \mathrm{UH}$ Navigator completed & 32.80 & 3.947 & \\
\hline $200,000-250,000$ cells $/ \mathrm{mL} \times \mathrm{UH}$ Navigator completed & 20.85 & 4.310 & \\
\hline$>250,000$ cells $/ \mathrm{mL} \times \mathrm{UH}$ Navigator completed & Ref. & - & \\
\hline BMSCC $2011 \times$ UH Checklist completed & & & $<0.0001$ \\
\hline$<150,000$ cells $/ \mathrm{mL} \times \mathrm{UH}$ Checklist completed & 18.66 & 3.229 & \\
\hline $150,000-200,000$ cells $/ \mathrm{mL} \times \mathrm{UH}$ Checklist completed & 14.03 & 3.063 & \\
\hline 200,000-250,000 cells $/ \mathrm{mL} \times \mathrm{UH}$ Checklist completed & 9.47 & 3.267 & \\
\hline$>250,000$ cells $/ \mathrm{mL} \times \mathrm{UH}$ Checklist completed & Ref. & - & \\
\hline
\end{tabular}

${ }^{1} \mathrm{UH}=$ Udder Health

${ }^{2}$ Ref. $=$ reference group.

$\times$ UH Checklist, and UH Navigator $\times$ UH Checklist) and 3 tools $(\mathrm{UH}$ Workshop $\times \mathrm{UH}$ Navigator $\times \mathrm{UH}$ Checklist). Also, the average monthly BMSCC of 2011 was included. The term $\rho \varepsilon_{i j k}$ is an error term consisting of 2 components: $\rho$ is the within-farm correlation (assuming autocorrelation) and $\varepsilon_{i j k}$ is the random error term. Least squares means were calculated to compare the average monthly BMSCC of the farms that had completed and had not completed 1 of the tools. Good- ness of fit of the model was assessed by judging the residuals. The residuals were plotted against the fitted values and judged for peculiarities (Dohoo et al., 2009). Data editing and the statistical analyses (PROC MIXED) were performed using SAS software (version 9.2; SAS Institute Inc., Cary, NC).

The average monthly BMSCC varied throughout both years, with the highest values during the months of July, August, and September (Figure 1). The aver- 
age monthly BMSCC of the 12,782 farms was 205,000 cells/mL in 2011, whereas in 2012, the average monthly BMSCC was 199,000 cells $/ \mathrm{mL}$. A clear reason for this decrease in average monthly BMSCC cannot be found. A reduction in average monthly BMSCC between the years 2011 and 2012 was observed for both farms that completed the tools and farms that did not complete the tools. The level of BMSCC in 2011 was lower for farms that completed the UH Navigator in $2012(183,000$ cells $/ \mathrm{mL})$ than for farms that did not complete the UH Navigator in $2012(207,000$ cells $/ \mathrm{mL})$. Also, farms that completed the UH Checklist and the UH Workshop in 2012 had a lower average monthly BMSCC in 2011 (average monthly BMSCC of 193,000 and 188,000 cells $/ \mathrm{mL}$, respectively) than farms that did not complete these tools (average monthly BMSCC of 207,000 cells $/ \mathrm{mL}$ ). Therefore, it seems to be that especially the farmers with more interest in udder health completed the tools. Farms that completed the tools for at least $1 \mathrm{mo}$ had a lower average monthly BMSCC than farms that did not complete the tools (Table 1). Farms that completed the UH Navigator had, in the months after completion, an average monthly BMSCC of 176,000 cells $/ \mathrm{mL}$, whereas the farms that did not complete the UH Navigator had an average monthly BMSCC of 202,000 cells/mL. Farms that completed both the UH Navigator and the UH Checklist had, in the months after completion, an average monthly BMSCC of 168,000 cells/mL.

Both completing the $\mathrm{UH}$ Navigator and the $\mathrm{UH}$ Checklist had a significant association with a lower average monthly BMSCC (Table 2). Attending the $\mathrm{UH}$ Workshop was not significant in the final model.

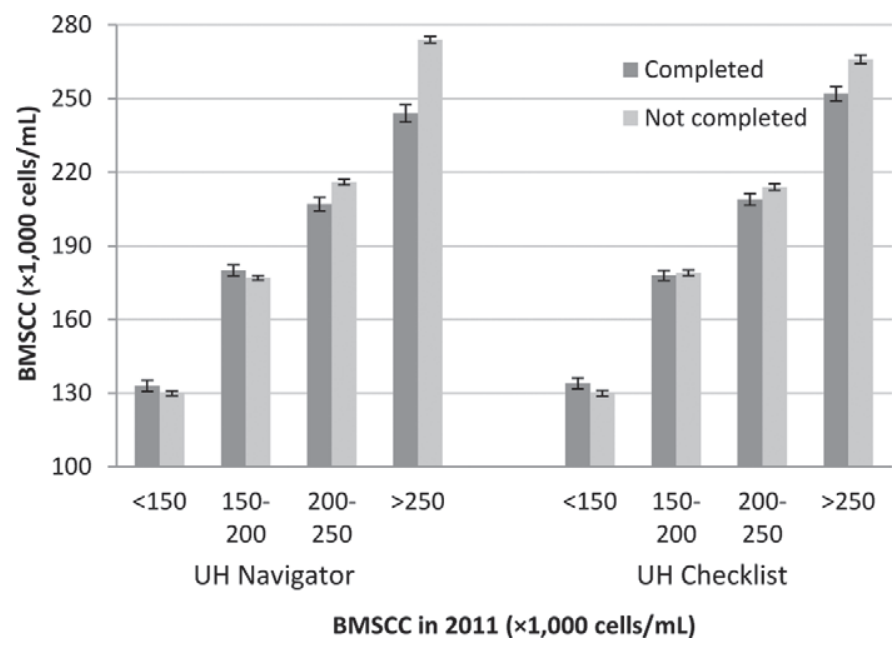

Figure 2. Estimated average monthly bulk milk SCC (BMSCC) for farms that completed and did not complete the Udder Health (UH) Navigator and UH Checklist for different levels of BMSCC in 2011. Values represent model predictions $(\mathrm{LSM} \pm \mathrm{SE})$.
The effect of the UH Workshop was significant when the other tools were not included, but the effect disappeared due to the other 2 tools. The absence of an effect for the UH Workshop was most probably because there was overlap in participation between the tools (the UH Workshop was attended by 605 farms, but 385 farms also participated in either the UH Navigator or the UH Checklist). The interaction terms between the tools had no significant association with the average monthly BMSCC. The level of the BMSCC in 2011, and the interaction terms with the tools UH Navigator and UH Checklist were significantly associated with the average monthly BMSCC. This means that the effect of these tools on the average monthly BMSCC appears to be different across different BMSCC levels in 2011. The effects of the UH Navigator and UH Checklist on the BMSCC were greater in herds with a BMSCC in 2011 of 200,000 to 250,000 cells/mL and even greater for herds with a BMSCC above 250,000 cells $/ \mathrm{mL}$ compared with herds with a BMSCC in 2011 of 150,000 to 200,000 cells/mL or less than 150,000 cells/mL (Figure 2).

This is an observational study, and the farmers decided themselves to complete the tools. The farms that decided to complete the tools had a lower average monthly BMSCC in 2011 than farms that did not complete the tools. It seems to be that especially the farmers with more interest in udder health completed the tools.

In conclusion, a reduction in average monthly BMSCC between the years 2012 and 2011 was observed for both farms that completed the tools and farms that did not complete the tools. The farms decided themselves to complete the tools and were, thus, not randomly selected. The farms that completed the UH Navigator and the UH Checklist were associated with a reduction in the average monthly BMSCC. This observation was especially true for farms with a BMSCC in 2011 above 200,000 cells $/ \mathrm{mL}$. It is difficult to draw conclusions on the effect of the UH Workshop due to overlap in participation between the tools.

\section{ACKNOWLEDGMENTS}

The authors thank the Dutch dairy industry for providing data.

\section{REFERENCES}

Barbano, D. M., Y. Ma, and M. V. Santos. 2006. Influence of raw milk quality on fluid milk shelf life. J. Dairy Sci. 89:E15-E19.

Barkema, H. W., Y. H. Schukken, T. J. G. M. Lam, M. L. Beiboer, G. Benedictus, and A. Brand. 1998. Management practices associated with low, medium, and high somatic cell counts in bulk milk. J. Dairy Sci. 81:1917-1927.

Berry, D. P., B. O'Brien, E. J. O'Callaghan, K. O. Sullivan, and W. J. Meaney. 2006. Temporal trends in bulk tank somatic cell count 
and total bacterial count in Irish dairy herds during the past decade. J. Dairy Sci. 89:4083-4093.

Cicconi-Hogan, K. M., M. Gamroth, R. Richert, P. L. Ruegg, K. E. Stiglbauer, and Y. H. Schukken. 2013. Associations of risk factors with somatic cell count in bulk tank milk on organic and conventional dairy farms in the United States. J. Dairy Sci. 96:36893702 .

Dohoo, I. R., S. W. Martin, and H. Stryhn. 2009. Veterinary Epidemiological Research. Atlantic Veterinary College Inc., Charlottetown, PE, Canada.

Dufour, S., A. Fréchette, H. W. Barkema, A. Mussell, and D. T. Scholl. 2011. Invited review: Effect of udder health management practices on herd somatic cell count. J. Dairy Sci. 94:563-579.

Ellis-Iversen, J., A. J. C. Cook, E. Watson, M. Nielen, L. Larkin, M. Wooldridge, and H. Hogeveen. 2010. Perceptions, circumstances and motivators that influence implementation of zoonotic control programs on cattle farms. Prev. Vet. Med. 93:276-285.

Elmoslemany, A. M., G. P. Keefe, I. R. Dohoo, and B. M. Jayarao. 2009. Risk factors for bacteriological quality of bulk tank milk in Prince Edward Island dairy herds. Part 2: Bacteria count-specific risk factors. J. Dairy Sci. 92:2644-2652.

Hogeveen, H., K. Huijps, and T. Lam. 2011. Economic aspects of mastitis: New developments. N.Z. Vet. J. 59:16-23.
Huijps, K., H. Hogeveen, T. Lam, and A. Lansink. 2010. Costs and efficacy of management measures to improve udder health on Dutch dairy farms. J. Dairy Sci. 93:115-124.

Jansen, J., R. J. Renes, and T. Lam. 2010a. Evaluation of two communication strategies to improve udder health management. J. Dairy Sci. 93:604-612.

Jansen, J., G. van Schaik, R. J. Renes, and T. Lam. 2010b. The effect of a national mastitis control program on the attitudes, knowledge, and behavior of farmers in the Netherlands. J. Dairy Sci. 93:5737-5747.

Lam, T. J. G. M., B. H. P. van den Borne, J. Jansen, K. Huijps, J. C. L. van Veersen, G. van Schaik, and H. Hogeveen. 2013. Improving bovine udder health: A national mastitis control program in the Netherlands. J. Dairy Sci. 96:1301-1311.

Sischo, W. M., N. E. Kiernan, C. M. Burns, and L. I. Byler. 1997 Implementing a quality assurance program using a risk assessment tool on dairy operations. J. Dairy Sci. 80:777-787.

UGCN (Udder Health Centre Netherlands). 2013. Uiergezondheidswijzer. Accessed July 31, 2013. http://www.ugcn.nl/nl/25222885Controle.html.

Velthuis, A. G. J., M. P. M. Meuwissen, and R. B. M. Huirne. 2009. Distribution of direct recall costs along the milk chain. Agribusiness 25:466-479. 